https://doi.org/10.5800/GT-2017-8-3-0264

\title{
EARLY CRETACEOUS EXTENSION IN UPPER-MIDDLE CRUST OF NE ASIA: EVIDENCES FROM WIDESPREAD SYN-THINNING GRANITIC DOMES
}

\author{
Lei Guo1, Tao Wang1, Ying Tong1, Enkh-Orshikh Orsoo1, 2, \\ Narantsetseg Tserendash², Lei Zhang1 \\ ${ }^{1}$ Institute of Geology, Chinese Academy of Geological Sciences, Beijing, China \\ 2 Institute of Paleontology and Geology, Mongolian Academy of Sciences, Ulaanbaatar, Mongolia
}

For citation: Guo L., Wang T., Tong Y., Orsoo E.-O., Tserendash N., Zhang L., 2017. Early Cretaceous extension in uppermiddle crust of NE Asia: evidences from widespread syn-thinning granitic domes. Geodynamics \& Tectonophysics 8 (3), 471-472. doi:10.5800/GT-2017-8-3-0264.

Numerous Early Cretaceous syn-thinning granitic domes are widespread in Mongolia and China-Mongolia border area. We observed relationships between deformation and magmatic activity that occurred in Baoder, Naran, Hanwula, Erdene, Altanshiree, Nartyn dome[Daoudene et al., 2012; Cheng et al., 2014; Guo et al., 2015], which developed in eastern Mongolia and China-Mongolia border area during Early Cretaceous crust-scale NW-SE extension.

These domes consist of core Early Cretaceous granitic pluton $(\sim 130 \mathrm{Ma})$, ductile shear zone and brittle detachment fault from center to outside. The hanging walls are undeformed pre-Cretaceous granodiorite, Devonian schists and Early Cretaceous basin. Ductile shear zone and detachment fault mostly developed in the southwestern part of these domes. Detailed field observation and microstructures showed that all the core pluton and ductile shear zones were formed in a same tectonic stress field, which indicated a unified top-to-the-NW shearing. The deformation grade increased toward outside. All those implied that formation of foliations of those domes are closely related to emplacement and uplift of the core plutons.

The granitoids in core plutons have geochemical similarities in major and trace elements. They are all plotted in the HKCA field and show high $\mathrm{Fe}^{*}$ values that fall in the A-type granites field, similar to other Early Cretaceous A-type and highly fractioned I-type granites (with A-type characteristics) in the nearby regions [Wang et al., 2015]. 
Thus, we suggest that these domes imply a unified top-to-the-NW shearing in the upper and middle crust with syn-thinning magmatism. They are similar to other extensional structures in NE Asia [Wang et al.,
2011, 2012], which reflected geological features of syn-kinematic magma emplacement during collapse of thickened crust caused by the closure of MongolOkhotsk ocean.

\section{REFERENCES}

Cheng Y.H., Teng X.J., Li Y.F., Yang J.Q., Liu Y., Peng L.N., Li Y., Li M., 2014. Chronology constraint and tectonic evolution of Hanwula Early Cretaceous ductile shear belt in Dong Ujimqin, Inner Mongolia. Journal of Earth Science (Journal of China University of Geosciences) 39 (4), 375-386 (in Chinese with English abstract).

Daoudene Y., Gapais D., Ruffet G., Gloaguen E., Cocherie A., Ledru P., 2012. Syn-thinning pluton emplacement during Mesozic extension in eastern Mongolia. Tectonics 31 (3), TC3001. https://doi.org/10.1029/2011TC002926.

Guo L., Li J.B., Tong Y., Wang T., Mo N., Zeng T., Jiao Y.Y., 2015. The identification of Early Cretaceous Baoder extensional granitic dome in Sonid Left Banner, Inner Mongolia, and its tectonic implications. Geological Bulletin of China 34 (12), 2195-2202 (in Chinese with English abstract).

Wang T., Guo L., Zhang L., Yang Q.D., Zhang J.J., Tong Y., Ye K., 2015. Timing and evolution of Jurassic-Cretaceous granitoid magmatisms in the Mongol-Okhotsk belt and adjacent areas, NE Asia: Implications for transition from contractional crustal thickening to extensional thinning and geodynamic settings. Journal of Asian Earth Sciences 97 (Part B), 365-392. https://doi.org/10.1016/j.jseaes.2014.10.005.

Wang T., Guo L., Zheng Y.D., Donskaya T., Gladkochub D., Zeng L.S., Li J.B., Wang Y.B., Mazukabzov A., 2012. Timing and processes of late Mesozoic mid-lower-crustal extension in continental NE Asia and implications for the tectonic setting of the destruction of the North China craton: Mainly constrained by zircon U-Pb ages from metamorphic core complexes. Lithos 154, 315-345. https://doi.org/10.1016/j.lithos.2012.07.020.

Wang T., Zheng Y.D., Zhang J.J., Zeng l.S., Donskaya T., Guo L., Li J.B., 2011. Pattern and kinematic polarity of Late Mesozoic extension in continental NE Asia: perspectives from metamorphic core complexes. Tectonics 30 (6), TC6007. https://doi.org/10.1029/2011TC002896. 